\title{
Preparation of peroxide of hydrogen
}

\section{Thenard}

To cite this article: M. Thenard (1833) Preparation of peroxide of hydrogen, Philosophical Magazine Series 3, 2:11, 403-404, DOI: 10.1080/14786443308648069

To link to this article: http://dx.doi.org/10.1080/14786443308648069

册 Published online: 01 Jun 2009.

Submit your article to this journal $\pi$

LII Article views: 2

Q View related articles $₫$ 
acquires oxygen, appears to depend upon its physical properties; for when white lead is calcined in the same manner, the finest orange minium is obtained by three operations, and it acquires 2.23 per cent. of oxygen.

M. Dumas observes that in no one of these cases has the massicot in becoming minium combined with sufficient oxygen to convert it into a sesqui-oxide, which it is well known the common red lead is usually considered to be ; for in that case it would give out 3.33 per cent. oxygen instead of only $2 \cdot 23$; when oxygen gas was passed over it, $2 \cdot 4$ per cent. was the largest quantity of oxygen absorbed. This minium M. Dumas found to consist of about $64 \cdot 9$ of protoxide and 35.1 of peroxide of lead, or two atoms of the former and one atom of the latter; and this he considers to be the essential composition of the miniums of commerce, mixed, as his experiments show, with variable quantities of yellow oxide.-Ann. de Chim. et de Phys., tom. xlix. p. 398 .

PREPARATION OF PEROXIDE OF HYDROGEN. BY M. THENARD.

Those chemists who have prepared peroxide of hydrogen or oxygenated water, know that the peroxide of barium which they employ always contains oxide of manganese ; that this oxide comes from the porcelain retorts in which the nitrate of barytes is calcined, and that it occasions the decomposition of a large quantity of oxygenated water, at the moment of precipitating the solution. This decomposition in. creases the difficulty of the preparation; it is in fact the only real one. I attempted to neutralize the effects of the oxide of manganese, and accomplished it by the addition of a little phosphoric acid; phosphate of manganese is then formed, which does not act at all in decomposing the oxygenated water.

Having then dissolved the peroxide of barium in the muriatic acid, and obtained a liquor sufficiently charged with oxygen, 2, or at most 3 parts of concentrated phosphoric acid must be added for every 100 parts of oxide; the acid is to be supersaturated by hydrated and divided peroxide, which will precipitate the silica and alumina, the iron and oxide of manganese, the two latter in the state of phosphates. These four substances become immediately deposited in the state of flocks, and are to be collected on a cloth; the liquor will readily pass through, and may be filtered as wanted.

In order that the operation may succeed well, it is requisite that the saturation by means of peroxide of barium should be attempted only with a tolerably clear solution. The presence of much sulphate of barytes would be an obstacle to collecting the precipitate, and to the filtration through linen.

When the liquor is carried to such a point as to contain only water, peroxide of hydrogen and muriate of barytes, sulphate of silver is to be added in powder; this is to be very slightly acid, and may be obtained by calcining pure nitrate of silver with sulphuric acid in a platina crucible. The whole is to be stirred with a glass rod, and when the muriate of barytes is quite or nearly decomposed, it will be known by the liquor becoming clear; then, in order to attain the point of perfect 
decomposition, small quantities of a very dilute solution of muriate of barytes, or of sulphate of silver, are to be added, as either salt may be in excess. In this, as in the preceding case, the liquor ought to be again passed through linen, to separate the precipitated matters. It is certainly possible to obtain the liqunr perfectly neutral, but it is better that the sulphuric acid should be slightly in excess; a little barytes water will afterwards precipitate it, and all chance of decomposing the peroxide of hydrogen will be avoided.

Lastly, having filtered the liquor through paper, it is to be concentrated as usual under the receiver of the air-pump. There is no difficulty in charging it very quickly with 60 to 80 times its volume of oxygen by the processes which have been described, before any concentration; only instead of dissolving the peroxide in a glass vessel, it is much more convenient to do it in a platina or silver vessel surrounded with ice, and to rub continually with a pestle the hydrated and divided peroxide.-Ann. de Chim. et de Phys., tom. 1. p. 80 .

\section{COMPOSITION OF CAFFEIN.}

MM. Pfaff and Liebig have analysed caffein, and find it to be composed of, taking the mean of two experiments,

$$
\begin{array}{lr}
\text { Carbon } & 4986 \\
\text { Hydrogen } & 5.32 \\
\text { Azote } & 29.03 \\
\text { Oxygen } & 15.80 \\
\hline & 100.01
\end{array}
$$

\begin{tabular}{|c|c|c|}
\hline $\begin{array}{l}\text { Four atoms carhon } \\
\text { Five atoms hydrogen } \\
\text { Two atoms azote } \\
\text { One atom oxygen }\end{array}$ & $\begin{array}{l}3 \cdot 05750 \\
0 \cdot 31199 \\
1 \cdot 77036 \\
1 \cdot 00000\end{array}$ & $\begin{array}{r}\text { or } 49.79 \\
5.08 \\
28 \cdot 83 \\
16 \cdot 30\end{array}$ \\
\hline & & $100 \cdot 00$ \\
\hline
\end{tabular}

which they consider as equivalent to

At the request of MM. Pfaff and Liebig, M. Wohler also analysed caffein, and with results almost precisely similar to those above stated. -Ann.de Chim. et de Phys., tom. xlix. p. 303.

To the analysis, the authors have appended the following observations, which constitute a fine example of the confusion which chemistry is doomed to suffer from the wild theories and speculations which are now so rapidly rising into fashion :-

"According to its theoretic composition, caffein may be regarded as a combination of a cyanic acid, which contains one half less oxygen than the common acid, with æther analogous to cyanic æther. An æther formed of a problematical cyanous acid would be composed of, $\mathrm{C}^{2} \frac{\mathrm{I}}{2} \mathrm{O}+\left(\mathrm{C}^{2} \mathrm{H}^{4}+\frac{1}{2} \mathrm{O} \mathrm{H}^{2}\right)=\mathrm{C}^{4} \mathrm{H}^{5} \mathrm{~N}^{2} \mathrm{O}$; this formula is the same as that of caffein."

R. P.

ANALYSIS OF THE SULPHO-PLUMBIFEROUS TELLURIVM.

M. Berthier remarks that the only ore of Tellurium which can be 